\title{
Surface Modification of Alumina Nanoparticles with Silane Coupling Agents
}

\author{
Luis A. S. A. Prado, ${ }^{*}, a$ Montira Sriyai, ${ }^{a}$ Marcos Ghislandi, ${ }^{a}$ Ana Barros-Timmons ${ }^{b}$ and \\ Karl Schulte ${ }^{a}$
}

${ }^{a}$ Institut für Kunststoffe und Verbundwerkstoffe (M-11), Technische Universität Hamburg-Harburg, Denickestrasse 16, D-21073 Hamburg, Germany

${ }^{b}$ Departament of Chemistry-CICECO, University of Aveiro, 3810193 Aveiro, Portugal

\begin{abstract}
No presente trabalho nós descrevemos a modificação da superfície de nanopartículas de alumina utilizando alcoxissilanos possuindo grupos epóxi (agentes de acoplamento baseados em silano, SCA). Os materiais foram caracterizados por espectroscopia de infravermelho e ressonância magnética nuclear de estado sólido. Considerando-se que as nanopartículas de alumina podem ser modificadas com SCA, como evidenciado por ${ }^{13} \mathrm{C} C \mathrm{CPAS} \mathrm{RMN}$, a presença de grupos arilsulfonato na superfície da alumina promoveu a polimerização pelo mecanismo de abertura do anel epóxido, a qual facilitou a modificação da superfície de alumina pela SCA. Os resultados de difratometria de raios X de pó e ${ }^{27} \mathrm{Al}$ MAS RMN mostraram claramente que o processo de polimerização SCA e a modificação da superfície, não provocaram mudanças estruturais, nem transições de fase na alumina. A modificação da superfície causou uma diminuição na estabilidade térmica do material resultante em relação às nanopartículas de alumina pura.
\end{abstract}

In the present paper we describe the surface modification of alumina nanoparticles using epoxy-containing alkoxysilanes (silane coupling agents, SCA). The materials were characterized using infrared spectroscopy and solid-state nuclear magnetic resonance. Whereas, neat alumina nanoparticles could be expectedly modified with the afore mentioned SCA, as evidenced by ${ }^{13} \mathrm{C}$ CPMAS NMR, the presence of arylsulphonates at the surface of alumina caused the ringopening polymerization of the epoxide. This polymerization reaction facilitated the surface modification of alumina by the SCA. X-ray powder diffraction and ${ }^{27} \mathrm{Al}$ MAS NMR clearly demonstrated that in spite of the SCA polymerization, there were neither structural changes nor phase transitions in the alumina after the surface modification. The surface modification decreased the thermal stability of alumina, in comparison to pristine alumina nanoparticles. stability

Keywords: alumina, surface functionalization, structure-properties relationship, thermal

\section{Introduction}

Alumina and other oxides are widely found in many applications including support for catalysts, ${ }^{1}$ organometallic ${ }^{2}$ (including metal carbonyl clusters), ${ }^{3}$ metal-organic ${ }^{4}$ and luminescent compounds, ${ }^{5}$ formulations for dental applications, ${ }^{6}$ additives for polymer (nano)composites, ${ }^{7}$ ceramic membranes, ${ }^{8}$ pre-concentration reactors ${ }^{9}$ and stationary phases for chromatography ${ }^{10}$ to name a few.

When dealing with multi-component systems, the interface plays a decisive role on dispersion and adhesion between the continuous phase (matrix) and the additives (fillers). ${ }^{11}$ Therefore, the surface properties of metal

\footnotetext{
*e-mail:1.prado@tuhh.de
}

oxides (including alumina) have to be tailored in order to improve the filler-matrix adhesion. ${ }^{12}$ Alumina can be modified by carboxylates, sulfonates and fosfonates ${ }^{13}$ to incorporate hydrophobic (or hydrofilic character) and functional groups (e.g. amines), but silane coupling agents and other siloxane precursors have been most extensively used to modify the surface of alumina for different purposes. ${ }^{4,7,8,11,14}$ Silylated alumina can improve the thermo-oxidative stability of thermoplastic elastomers [poly(ether-block-amide), [poly(ether-bamide), PEBAX ${ }^{\circledR}$ polymers $],{ }^{14}$ and can be used for the immobilization of electrochemically active species such as metalloporphyrins. ${ }^{4}$

Coupling of organic groups onto the surface of oxides $\left(\mathrm{MO}_{\mathrm{x}}\right.$ : where $\mathrm{M}$ can be any transition metal, aluminum 
or silicon) using alkoxysilanes (e.g. $\mathrm{RSi}(\mathrm{OR} \text { ”) })_{3}$, where $\mathrm{R}$ can be any organic group or a hydride and R" is usually an alkyl group) occurs via the formation of siliconoxygen-heteroatom (Si-O-M or metallasiloxane) bonds (equations 2 and 3). In addition to participate in coupling reactions, the alkoxysilane can also hydrolyse (equation 1) and condensate into oligomeric siloxane (formation of $\mathrm{Si}-\mathrm{O}-\mathrm{Si}$ ) bonds as illustrated by equations 4 and $5 .{ }^{15}$

$$
\begin{aligned}
& \mathrm{RSi}(\mathrm{OR} ")_{3}+\mathrm{x} \mathrm{H}_{2} \mathrm{O} \rightarrow \\
& \mathrm{RSi}(\mathrm{OR} ")_{3-\mathrm{x}}(\mathrm{OH})_{\mathrm{x}}+\mathrm{x} \mathrm{R} \text { "-OH }(0<\mathrm{x}<3) \\
& \mathrm{RSi}(\mathrm{OR} ")_{3-\mathrm{x}}(\mathrm{OH})_{\mathrm{x}}+\equiv \mathrm{M}-\mathrm{OH} \rightarrow \\
& \mathrm{RSi}(\mathrm{OR})_{2-\mathrm{x}}(\mathrm{OH})_{\mathrm{x}}(\mathrm{O}-\mathrm{M} \equiv)+\mathrm{R} \text { "-OH }(0 \leq \mathrm{x}<3) \\
& \mathrm{RSi}(\mathrm{OR} ")_{3-\mathrm{x}}(\mathrm{OH})_{\mathrm{x}}+\equiv \mathrm{M}-\mathrm{OH} \rightarrow \\
& \mathrm{RSi}(\mathrm{OR} ")_{3-\mathrm{x}}(\mathrm{OH})_{1-\mathrm{x}}(\mathrm{O}-\mathrm{M} \equiv)+\mathrm{H}_{2} \mathrm{O}(0<\mathrm{x}<3) \\
& \mathrm{RSi}(\mathrm{OR} ")_{3-\mathrm{x}}(\mathrm{OH})_{\mathrm{x}}+\mathrm{RSi}(\mathrm{OR} ")_{3} \rightarrow \\
& \mathrm{RSi}(\mathrm{OR})_{3-\mathrm{x}}(\mathrm{OH})_{1-\mathrm{x}}(\mathrm{O}) \mathrm{RSi}(\mathrm{OR})_{2}+\mathrm{R} \text { "-OH }(0<\mathrm{x}<3) \\
& \mathrm{RSi}(\mathrm{OR} ")_{3-\mathrm{x}}(\mathrm{OH})_{1-\mathrm{x}}(\mathrm{O}) \mathrm{RSi}(\mathrm{OR})_{2}+\mathrm{R} \text { '-OH }(0<\mathrm{x}<3)
\end{aligned}
$$

When dealing with silane coupling agents containing reactive functional groups like epoxides it is assumed that this group remains intact after the functionalization of oxide surfaces. ${ }^{11,14}$ In previous studies on silylation of laponite using alkoxides, we observed the formation of oligomeric polysiloxanes attached to the layered silicate, ${ }^{15}$ which improved the compatibility between laponite and proton-conducting ionomers, allowing the preparation of new membranes for direct-methanol fuel cell applications. ${ }^{16}$ In the present paper, we focused on the study of the surface chemistry of a commercially available silane coupling agent (SCA), [2-(3,4-epoxycyclohexyl) ethyl]trimethoxysilane (Figure 1), at both pristine and $p$-toluenesulfonate-modified alumina nanoparticles surface. The results are discussed in terms of changes in the molecular structure of mentioned silane and its effect on the degree of functionalization of the alumina nanoparticles.

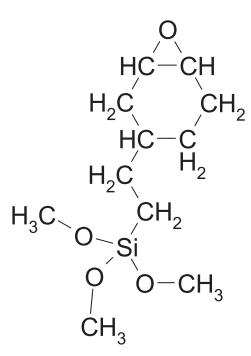

Figure 1. Structure of the silane coupling agent used in the present work.

\section{Experimental}

\section{Materials and methods}

Pristine alumina nanoparticles (AL-1, needles) and arylsulfonate modified alumina nanoparticles (AL-2, cubes with aspect ratio $=1$ ), kindly provided by Sasol, Germany, were dried under vacuum at $150{ }^{\circ} \mathrm{C}$ for at least $48 \mathrm{~h}$ before use. Silane coupling agent [2-(3,4-epoxycyclohexyl)ethyl] trimethoxysilane (SCA; CAS Number: 3388-04-3) and xylene (mixture of isomers) were purchased from Aldrich, Germany and used as received.

\section{Modification of alumina nanoparticles}

$50 \mathrm{~g}$ of alumina nanoparticles and $50 \mathrm{~g}$ of SCA in $200 \mathrm{~mL}$ of xylene were transferred to a $500 \mathrm{~mL}$ roundbottom flask equipped with a reflux condenser. The resulting white suspension was stirred and refluxed at $130{ }^{\circ} \mathrm{C}$ for $22 \mathrm{~h}$. The alumina was centrifuged and the beige precipitate was rinsed out with propan-2-ol to remove the excess of silane absorbed on the alumina. Finally, the modified alumina was dried in air at room temperature and then under vacuum at $150^{\circ} \mathrm{C}$, for $24 \mathrm{~h}$. The samples AL-S1 and AL-S2 were obtained from the coupling reaction with AL-1 and AL-2, respectively.

\section{Characterization of the modified alumina}

Fourier transform infrared spectra were recorded in a Matson 700 FTIR. The alumina samples were diluted in dry $\mathrm{KBr}$ and pressed into pellets. ${ }^{13} \mathrm{C},{ }^{27} \mathrm{Al}$ and ${ }^{29} \mathrm{Si} \mathrm{NMR}$ spectra were recorded on a Bruker AVANCE 400 (DSX) wide-bore spectrometer $(9.4 \mathrm{~T})$ at 100.62, 104.26 and $79.49 \mathrm{MHz}$, using a $4 \mathrm{~mm}$ double-bearing probe and zirconia rotors. ${ }^{13} \mathrm{C}$ CPMAS NMR and ${ }^{29} \mathrm{Si}$ CPMAS NMR spectra were recorded using a RAMP-CP shape (100 to $50 \%$ amplitude), $90^{\circ} \mathrm{rf}$ pulses of 3.5 and $4.25 \mathrm{~ms}$, contact times of 1.5 and $8 \mathrm{~ms}$, spinning rates of 9 and $5 \mathrm{kHz}$, and recycle delay time of $5 \mathrm{~s}$. The ${ }^{27} \mathrm{Al}$ MAS NMR spectra were recorded with short and powerful $(0.6 \mathrm{~ms}$, equivalent to $10^{\circ}$ ) rf pulses, $1 \mathrm{~s}$ recycle delay time and $14 \mathrm{kHz}$ spinning rate. XRD diffraction pattern were obtained in a Bruker D-8 Discover diffractometer using the $\mathrm{CuK}_{\alpha}$ radiation $(\lambda=0.15418 \mathrm{~nm})$.

Thermogravimetric analysis experiments were conducted with a TGA Q500 equipment (TA Instruments) under synthetic air. Two sets of experiments were carried out: (i) the samples were dried in a vacuum oven at $150^{\circ} \mathrm{C}$ for $48 \mathrm{~h}$ and heated from room temperature up to $750{ }^{\circ} \mathrm{C}$ at $10{ }^{\circ} \mathrm{C} \mathrm{min}^{-1}$; and (ii) the samples were heated from room 
temperature up to $180{ }^{\circ} \mathrm{C}$ (in the TGA equipment) and kept at this temperature for $20 \mathrm{~min}$ (i.e., until no changes in weight were observed). Then the samples were cooled down to room temperature and heated up to $750{ }^{\circ} \mathrm{C}$ using the same experimental conditions.

\section{Results and Discussion}

\section{Structural characterization of the modified aluminas}

The infrared spectra (Figure 2) of alumina nanoparticles AL-2 and AL-S2 have peaks in the 2960 and $2860 \mathrm{~cm}^{-1}$ range, which can be assigned to the stretching of the $\mathrm{C}-\mathrm{H}$ bonds ${ }^{4}$ of the silane coupling agent (SCA) used for the preparation of AL-S1 and AL-S2. Furthermore, the broad absorption in the $1200-950 \mathrm{~cm}^{-1}$ range, ${ }^{17}$ indicates the formation of Al-O-Si and Si-O-Si bonds. These vibrational modes appear at frequencies relatively close to that of Al-O-Al bonds, due to the similar mass of $\mathrm{Al}$ and $\mathrm{Si}$ atoms. The positions of the peaks associated to the $-\mathrm{OH}$ groups of alumina at 3092, 2090 and $1920 \mathrm{~cm}^{-1}$ can be used as fingerprints of the boehmite structure $(\gamma-\mathrm{AlOOH}) .{ }^{17}$

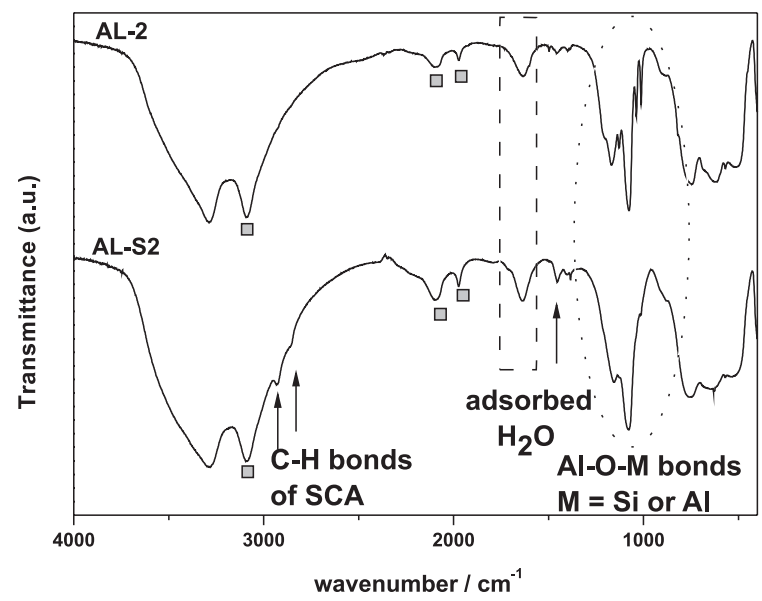

Figure 2. IR spectra of the AL-2 and AL-S2 evidencing the presence of the SCA at the surface of AL-S2 sample.

XRD plots of pristine and functionalized alumina samples are displayed in Figure 3. As evidenced by FTIR, the alumina samples are constituted by $\gamma$-AlOOH. ${ }^{18}$ As expected, there is no change in the crystallographic phase due to the functionalization process. Moreover, the peak width remained unchanged after sample functionalization, suggesting that the apparent crystal size of the nanoparticles did not increase upon treatment with silane coupling agents.

Further details on the chemical structure of the silane coupling agent at the surface of alumina nanoparticles can be extracted from the ${ }^{13} \mathrm{C}$ CPMAS NMR spectra of the functionalized alumina samples. The ${ }^{13} \mathrm{C}$ NMR spectra of

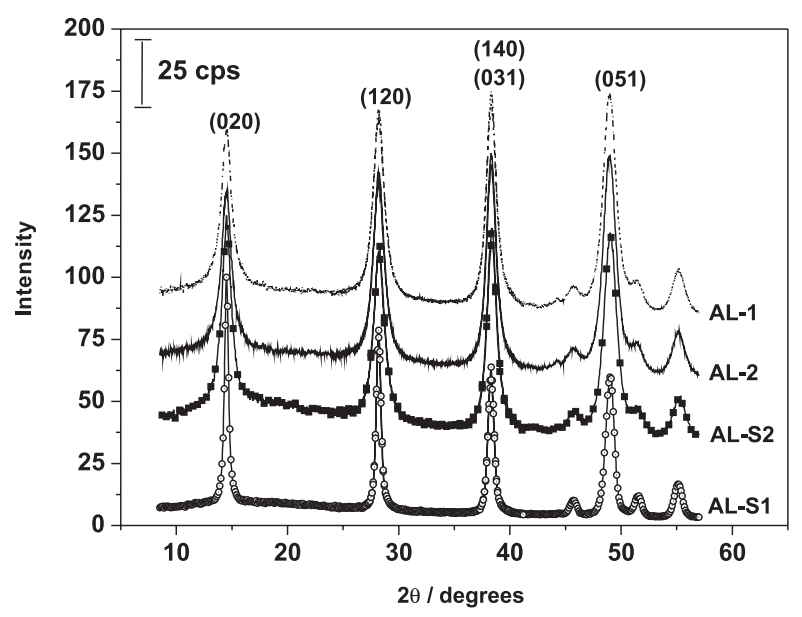

Figure 3. XRD patterns of the alumina samples investigated in this work. The curves were shifted vertically for the sake of clarity.

epoxy resins containing cyclohexene oxide was extensively investigated ${ }^{19}$ and the resonance peak associated with the epoxide ring can be seen at $\delta 53 \mathrm{ppm}$. Due to the broadening of the resonance peak in solid samples (anisotropy, crosspolarization), these two peaks could not be resolved (see Figure 4 and Table 1). Other important resonance peaks are related to the carbon atoms directly attached to the silicon $\left(\mathrm{C}_{\alpha}\right)$ at $\delta 10 \mathrm{ppm} .{ }^{20}$ This peak is relatively intense for the functionalized alumina needles, whereas its is weak in the functionalized alumina previously treated with p-toluenesulfonate anions (as supplied by Sasol, Germany). ${ }^{13}$

Table 1. ${ }^{13} \mathrm{C}$ CPMAS NMR analysis of silylated alumina nanoparticles

\begin{tabular}{lcc}
\hline Assignment $^{19-22}$ & AL-S1 $(\delta$ ppm $)$ & AL-S2 $(\delta$ ppm $)$ \\
\hline $\mathrm{C}_{\alpha}$ & 10 & 10 \\
$\mathrm{C}_{\beta}, \mathrm{C}_{3}, \mathrm{C}_{4}, \mathrm{C}_{6}$ & $25 ; 30$ & $25 ; 30$ \\
$\mathrm{C}_{1}, \mathrm{C}_{2}$ (epoxide ring) & 53 & not detectable \\
Openned epoxide ring & $69 ; 76$ & $69 ; 76$ \\
Aromatic & not detectable & 128 \\
\hline
\end{tabular}

The peaks at $\delta 127$ and 132 ppm only could be seen in the ${ }^{13} \mathrm{C}$ NMR spectra of the silanized alumina nanoparticles having lower aspect ratio (AL-S2) and indicates the presence of $p$-alkylsulfonate anions. ${ }^{21}$ Although the expected peak at $\delta 145 \mathrm{ppm}$ (associated with the carbon atom directly bond to the sulfonate group of arylsulfonates) could not be identified in the spectra of AL-S2 sample, due to the low intensity of the signal associated to quartenary carbon atoms (i.e., carbon atoms bond to any atom other than hydrogen) that signal should be much weaker in the case of solid samples. The presence of sulfur was confirmed by elemental analysis of the AL-S2 sample (S: 0.2\%).

High loadings of sulfur were also found for the alumina nanoparticles prior to the silanization process (S: $2.6 \%)$. 

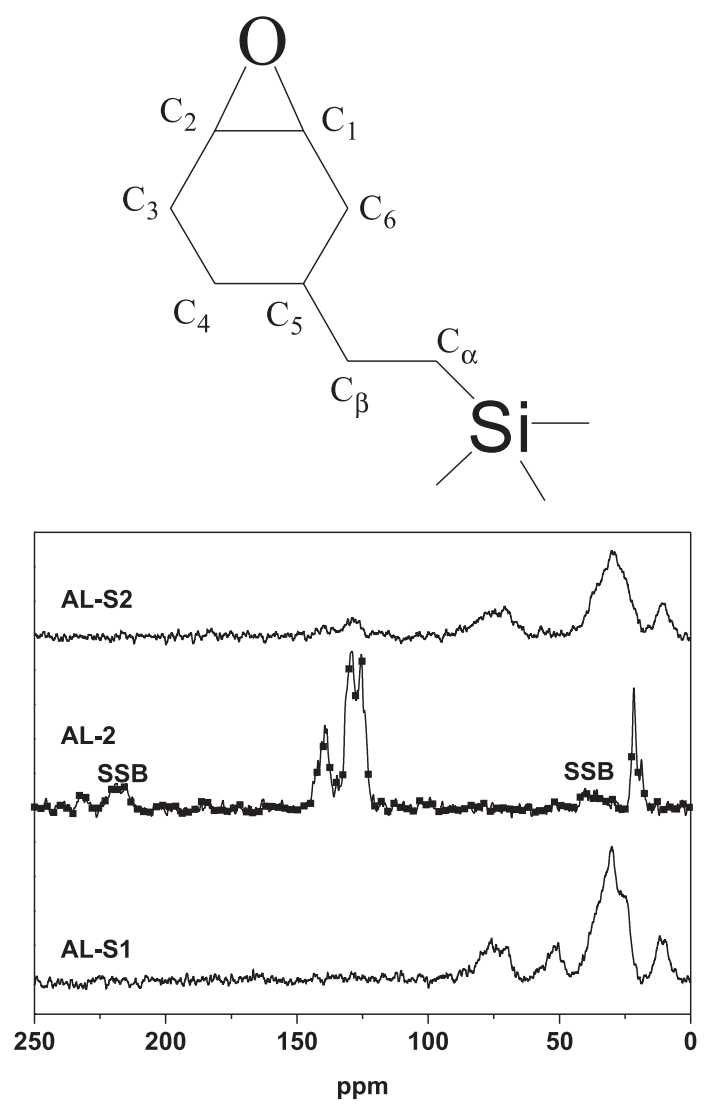

Figure 4. Chemical structure of the SCA at the surface of AL-S1 and ${ }^{13} \mathrm{C}$ CPMAS NMR spectra of the AL-S1, AL-2 and AL-S2 showing the different kinds of functionalization at the surface of these samples. (SSB and $\mathrm{C}_{\alpha}$-Si denote spinnig side band and carbon atom attached to the silicon atom, respectively).

The presence of carbon in the alumina nanoparticles after the silanization process is another strong indication that sulfonates rather than sulfates are present at the surface of the functionalized materials.

At this point it is worth emphasizing the role of the sulfonate groups on the integrity of the cyclohexene oxide moiety of the silane coupling agent used for the silanization of both types of alumina nanoparticles. For the AL-S1 (silylated needle-like nanoparticles), which do not contain any sulfonate group, the resonance peak at $\delta 53 \mathrm{ppm}$ is clearly observed indicating that the epoxy group is still present in these samples. On the other hand, the ${ }^{13} \mathrm{C}$ NMR spectrum of the AL-S2 has a very weak peak at $\delta 53 \mathrm{ppm}$, which suggests a partial degradation of the epoxide group. Since both silylated aluminas were prepared using the same conditions, and considering that the only difference between them is the presence of the $p$-alkylbenzenesulfonate anion at the surface of the AL-S2, one can infer that this anion somehow contributes to the decomposition of the epoxide group.

The peaks at $\delta 67$ and $76 \mathrm{ppm}$, cannot be assigned to the cyclohexene oxide moiety, ${ }^{19}$ but to the $\mathrm{C}-\mathrm{OH}$ groups resulting from the nucleophillic attack of the epoxy ring and its derivatives (silyl ester, or organic esters). Similar chemical shifts can be observed, for instance, for 1,2-cyclohexanediol ${ }^{22}$ and poly(cyclohexene oxide). ${ }^{22}$ Since these peaks are present in the ${ }^{13} \mathrm{C}$ CPMAS spectra of both types of silylated alumina prepared in this work, it can be assumed that the alumina surface itself is acidic enough to open the epoxide ring, yielding substituted 1,2-cyclohexanediol. The proposed reaction mechanism will be discussed in details in the following sections of this manuscript.

The peak associated to the epoxy ring (at $\delta 53 \mathrm{ppm}$ ) can be hardly recognized in the spectra of the AL-S2 sample. Therefore, the sulfonate anions present at the surface of this material might play a role on the decomposition of the cyclohexene oxide moiety of the silane coupling agent. In fact metal sulfonates are known to be useful catalysts for the attack of epoxides by amines, ${ }^{23}$ and can even catalize the polymerization of epoxides. ${ }^{24} \mathrm{~A}$ silanol-assisted polymerization mechanism of cyclohexene oxide catalyzed by aluminum (III) salts was also described by Hayase and co-workers, ${ }^{25}$ whereas magadiite, an acidic layered silicate, has been also reported to promote the polymerization of cyclohexene oxide. ${ }^{22}$ Therefore, a sulfonate-assisted decomposition mechanism of the silane coupling agent, accelerated by the acidic alumina surface, seems to be reasonable for explaining the enhanced degradation of the SCA by the modified alumina surface, during the production of AL-S2 sample.

The formation of a polysiloxane layer at the surface of AL-S2 was confirmed by the ${ }^{29} \mathrm{Si}$ CPMAS NMR spectrum (Figure 5), which presented two peaks at $\delta-57.1$ and $-62.8 \mathrm{ppm}$ assigned to $\mathrm{T}_{2}\left(\mathrm{CSiO}_{2 / 2} \mathrm{OH}\right.$ silanol groups $)$ and $\mathrm{T}_{3}\left(\mathrm{CSiO}_{3 / 2} \mathrm{OH}\right.$, fully condensed silsesquioxane $)$ units. ${ }^{26}$ The presence of $\mathrm{T}_{2}$ and $\mathrm{T}_{3}$ peaks indicated the formation of siloxane and/or aluminosiloxane bonds, in agreement with the FTIR results. The absence of peaks associated to silica and/or aluminosilicates (ranging from -90 to $-120 \mathrm{ppm}$ ) indicates that the SCA did not undergo Si-C scission during the functionalization process.

${ }^{27} \mathrm{Al}$ CPMAS NMR experiments provided further information on structural changes on the boehmite phase due to the functionalization process. Although XRD did not show any evidence for such transformation, no evidence of formation of amorphous alumina phase was found after functionalization. Figure 6 displays the ${ }^{27} \mathrm{Al}$ MAS NMR spectra of the samples studied in the present work. The hexa-coordinated $\mathrm{Al}^{3+}$ species in alumina can be recognized as a sharp peak centred at $\delta 7 \mathrm{ppm},{ }^{27}$ which is present in the spectra of AL-S1, AL-S2, AL-1 and AL-2 samples. The absence of resonance peaks in the $\delta 70$ to $20 \mathrm{ppm}$ range, 


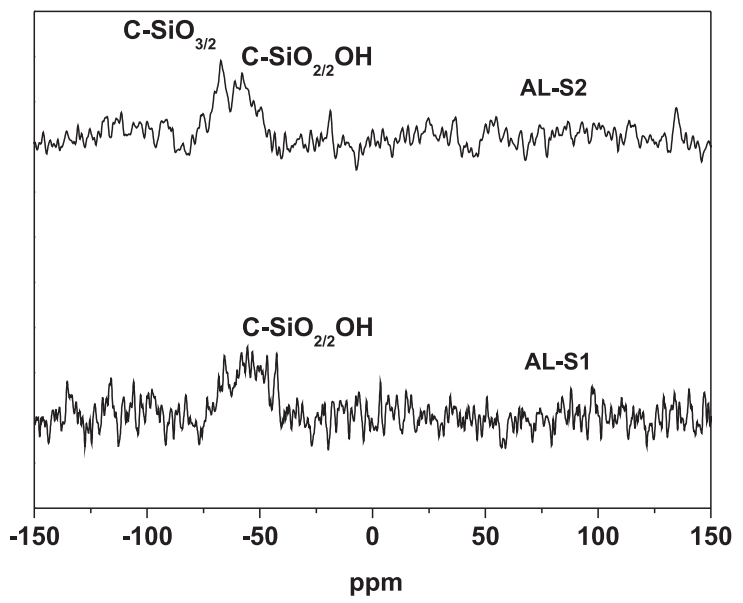

Figure 5. ${ }^{29} \mathrm{Si}$ CPMAS NMR spectra of the AL-S1, and AL-S2 confirming the presence of organosiloxanes (alkylsilsesquioxanes) at the surface of these samples.

which are usually associated to tetra-coordinated ${ }^{28}$ or penta-coordinated ${ }^{27} \mathrm{Al}^{3+}$ species, strongly indicates that the chemical environment of the $\mathrm{Al}^{3+}$ ions remained unchanged after the functionalization process.

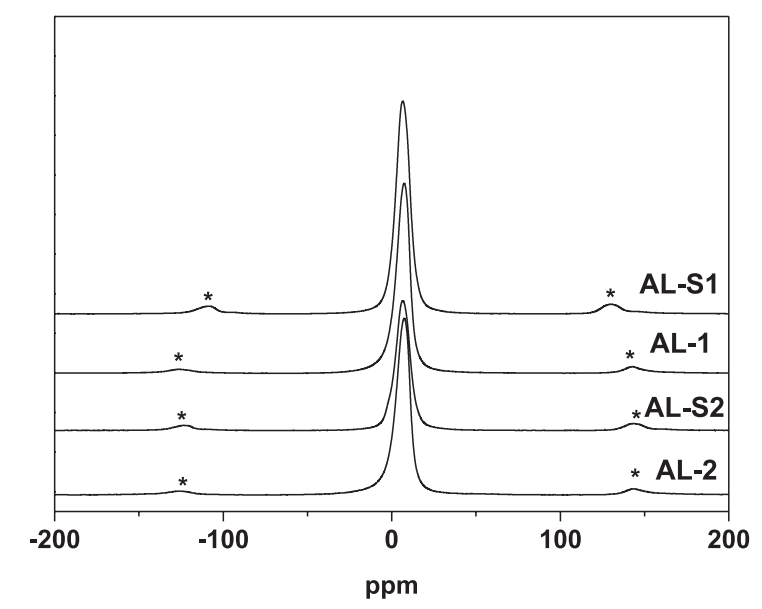

Figure 6. ${ }^{27} \mathrm{Al}$ MAS NMR spectra of the alumina samples investigated in this study (* denotes the spinning side bands).

\section{Evaluation of the thermal stability}

The thermal stability of the materials was assessed by TGA. The dried samples exhibited relatively simple degradation patterns, which can be summarized in two steps: $i$ ) breakage of $\mathrm{Si}-\mathrm{C}$ bonds of the silane coupling agent starting at $320-330{ }^{\circ} \mathrm{C} ; 2^{29} \mathrm{ii}$ ) dehydroxylation of boehmite (at temperatures higher than $450{ }^{\circ} \mathrm{C}$ ). $.18,30$

The temperature corresponding to $5 \%$ weight loss $\left(\mathrm{T}_{5}\right)$ was considered as the onset of the degradation process in accordance to previous publications. ${ }^{15,31}$ Considering the dried samples, the silylated aluminas are slightly less stable against oxidation than the AL-1 and AL-2 samples, as indicated by the $-12{ }^{\circ} \mathrm{C}$ decrease of $\mathrm{T}_{5}$ of the silylated samples in comparison to their respective starting materials (see Figure 7). This can be explained by the lower thermal stability of the siloxane layer (semi-inorganic material) in comparison with the starting materials. It should be stressed out that the amount of organic components determines the thermal-oxidative
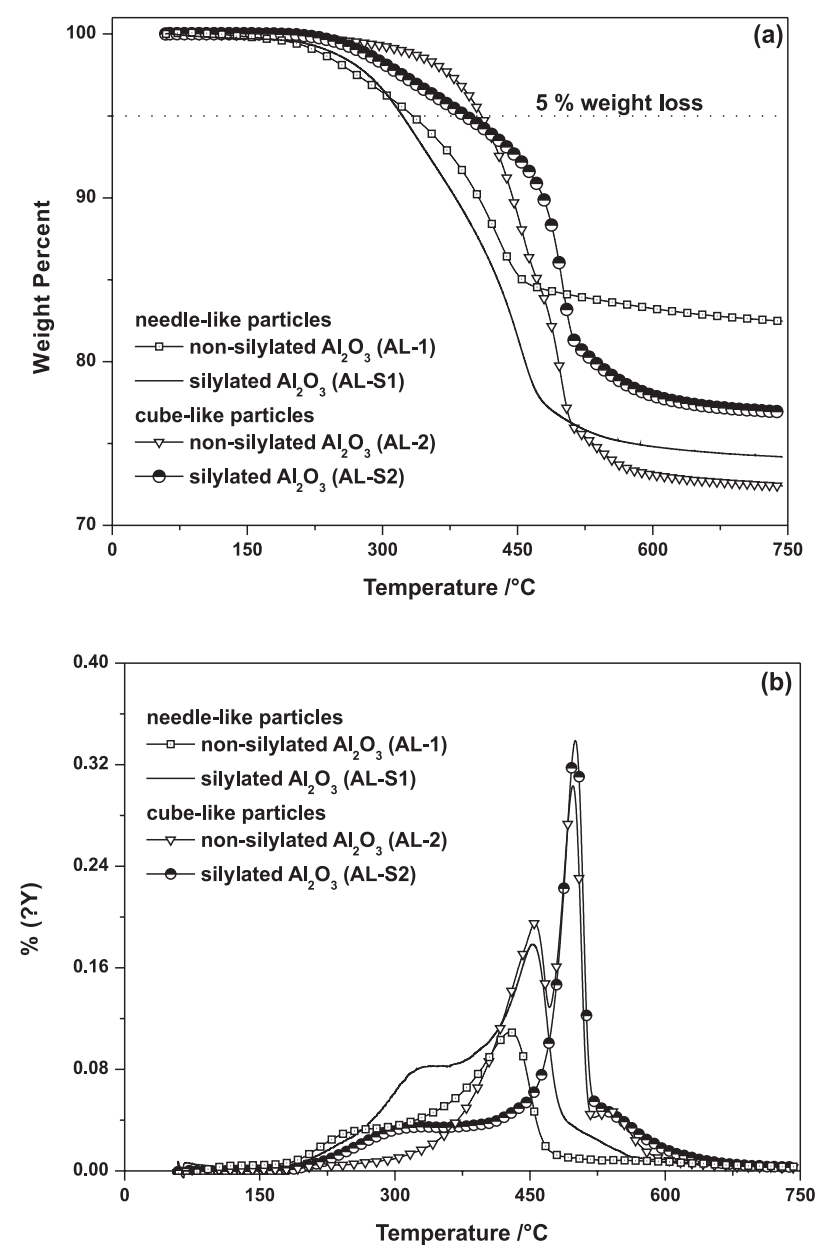

Figure 7. TGA (a) and DTGA (b) curves of the alumina samples investigated in this work. The samples were previously dried at $150{ }^{\circ} \mathrm{C}$ (in vacuum oven) for $48 \mathrm{~h}$ prior to the analysis.

Table 2. Evaluation of thermo-oxidative stability of the dried and nondried AL-1, AL-S1, AL-2 and AL-S2 samples

\begin{tabular}{lcccccc}
\hline Sample & $\begin{array}{c}\mathrm{T}_{5} \\
\left({ }^{\circ} \mathrm{C}\right)\end{array}$ & $\begin{array}{c}\mathrm{T}_{\text {sh }}{ }^{\mathrm{a}} \\
\left({ }^{\circ} \mathrm{C}\right)\end{array}$ & $\begin{array}{c}\mathrm{T}_{\max }{ }^{\mathrm{b}} \\
\left({ }^{\circ} \mathrm{C}\right)\end{array}$ & $\begin{array}{c}\text { Ceramic } \\
\text { yield }(\%)\end{array}$ & $\begin{array}{c}\mathrm{T}_{5}{ }^{\mathrm{c}} \\
\left({ }^{\circ} \mathrm{C}\right)\end{array}$ & $\begin{array}{c}\text { Volatiles }^{\mathrm{d}} \\
(\%)\end{array}$ \\
\hline AL-1 & 334 & 244 & 429 & 82.5 & 67 & 9.6 \\
AL-S1 & 322 & 344 & 454 & 74.2 & 292 & 2.5 \\
AL-2 & 410 & - & $456 ; 497$ & 72.4 & 121 & 4.6 \\
AL-S2 & 392 & 305 & 500 & 76.9 & 358 & 1.3 \\
\hline
\end{tabular}

${ }^{\mathrm{a}} \mathrm{T}_{\mathrm{sh}}$ is the onset temperature of the shoulder of the DTGA curve; ${ }^{\mathrm{b}} \mathrm{T}_{\text {max }}{ }^{\mathrm{sa}}$ corresponds to the temperature associated to the maximum mass flux from solid to vapour; 'determined for the non-dried samples; ${ }^{\mathrm{d}}$ weight loss of the non-dried sample up to $180^{\circ} \mathrm{C}$ (see text for details). 
stability of the alumina samples investigated in the present work.

The ceramic yield (or residual weight percent) might be used as criterion for the evaluation of the amount of organic modification of the alumina samples, since under the experimental conditions used for TGA, the organic moieties are completely decomposed forming white residues. Therefore, the formation of silicon carbide and/ or silicon oxycarbide glasses due to the decomposition of polysiloxanes $^{29}$ can be disregarded. In fact, AL-1 (pure alumina nanoparticles) has the highest ceramic yield of this set of samples $\left(82.5 \%\right.$ at $750{ }^{\circ} \mathrm{C}$ under synthetic air). On the other hand, the ceramic yield for AL-2 nanoparticles is $72.4 \%$, due to the decomposition of the arylsulfonates at the surface of these nanoparticles. Treatment of alumina samples with distinct surface characteristics with silanes caused different changes in the ceramic yield. AL-S1 has lower ceramic yield than its precursor due to the elimination of the organic groups attached to the silicon and oxygen atoms of the SCA.

On the other hand, AL-S2 has ceramic yield (76.9\%) higher than its precursor AL-2 (72.4\%). This fact cannot be solely due to the lower stability of the SCA organic groups. The amount of arylsulfonate in AL-S2 might be lower than in AL-2. This hypothesis is supported also by the ${ }^{13} \mathrm{C}$ CPMAS NMR results discussed in the previous sections, since the peak of the aromatic carbon has lower intensity for AL-S2 than for its precursor AL-2. If the arylsulfonate participated in the degradation of the cyclohexene oxide moiety of the SCA, the expected product would be an arylsulphonate ester. Since arylsulfonate groups are good leaving groups, they might be hydrolysed or removed by any hydroxyl group in the reaction medium, giving rise to an arylsulphonic acid. Therefore, the thermal behavior of the AL-2 and AL-S2 samples is determined not only by the amount of SCA, but also by the amount of arylsulfonate groups at the surface. As a result, it is difficult to make any correlation between the changes in ceramic yield due to the interplay of these two parameters.

However, more detailed information on the effect of the silane modification on the degradation kinetics may be extracted from the DTGA curves (Figure 7b). The DTGA curve of AL-1 contains a shoulder and a defined peak; revealing two overlapped degradation processes (see Figure $7 \mathrm{~b}$ and Table 2). Both are shifted to higher temperatures after silanization of AL-1. In fact, the SCA reacts with the $\mathrm{Al}-\mathrm{OH}$ groups on the boehmite surface forming Al-O-Si (aluminosiloxane) bonds. Hence, the de-hydroxylation of boehmite is hindered due to the formation of aluminosiloxane bonds. The shoulder and peak temperatures $\left(\mathrm{T}_{\mathrm{sh}}\right.$ and $\mathrm{T}_{\max }$; respectively) are shifted +100 and $+25^{\circ} \mathrm{C}$, respectively. Therefore, this functionalization step changed considerably the thermal properties of the boehmite needles (AL-1). The TGA curve of the AL-2 sample (arylsulfonate treated alumina) exhibits two partially overlapping peaks centred at $\mathrm{T}_{\max } 456$ and $497^{\circ} \mathrm{C}$. Conversely, the DTGA curve of AL-S2 has only one defined peak centred at $500{ }^{\circ} \mathrm{C}$ and a shoulder with onset temperature at $305{ }^{\circ} \mathrm{C}$, which is associated to the postcondensation of the $\mathrm{Si}-\mathrm{OH}$ groups of the siloxane layer ${ }^{15}$ and the onset of the thermal activation of Si-C bonds. ${ }^{29}$

A deeper understanding of the effect of silylation of alumina on their surface characteristics can be gained from the analysis of TGA curves of non-dried samples (Figure 8). The first thermal process is associated with water/moisture desorption (for AL-1 and AL-2) along with elimination of volatiles (e.g. methanol, water) due to post-condensation reactions at the surface of AL-S1 and AL-S2 samples. A weight loss of 9.2 and $4.6 \%$ during the first heating step of AL-1 and AL-2 samples can be explained by the previous treatment of AL-2 with arylsulfonates, which impart a hydrophobic character to the surface, leading to a decreased water adsorption by this sample. Concerning the non-dried AL-S1 and AL-S2 samples, it can be noticed that these samples lost 2.5 and $1.3 \mathrm{wt} \%$; respectively, due to volatiles (see Table 2). These weight losses are significantly lower than those observed for AL-1 and AL-2 samples. This fact can be explained in terms of enhanced hydrophobic character of the surface of AL-S1 and AL-S2 due to the polysiloxane layer. ${ }^{15}$

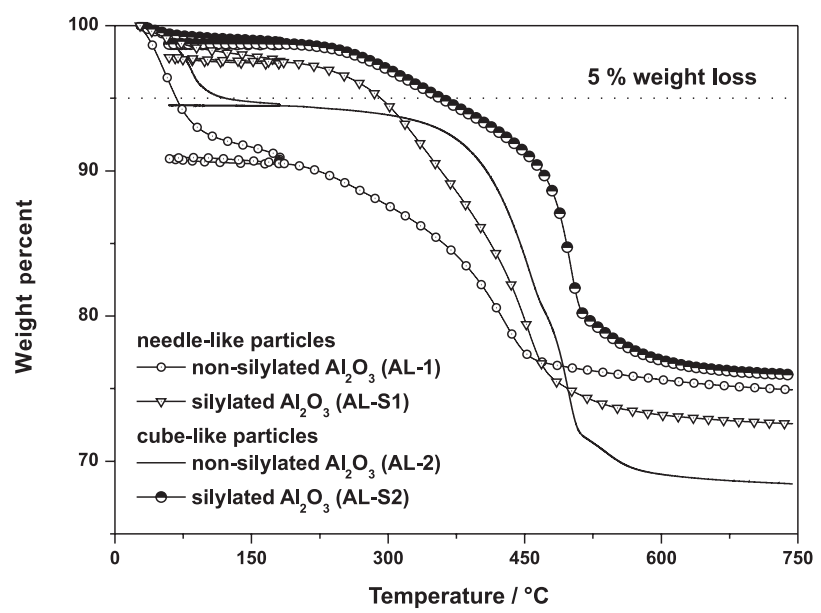

Figure 8. TGA curves of the alumina samples investigated in this work. The samples were analyzed under synthetic air without previous drying process.

The initial temperature of degradation of non-dried samples is an important parameter for the application of these materials, for instance in nanoparticle-reinforced materials and polymer membranes for moderately high temperature applications (e.g. fuel-cell membranes). As 
summarized in Table 2, the $\mathrm{T}_{5}$ values for the samples increases in the order AL-1 < AL-2 < AL-S1 < AL-S2 (see Figure 8). Since this process reflects the water release by these materials (which is strongly undesired for polymer processing through extrusion and injection molding), sample AL-S2 has the highest potential for industrial applications in advanced polymer nanocomposite materials, since it does not require long drying processes. Samples AL-2 and AL-S1 seem to be more suitable for applications requiring water-retention at moderate temperatures, for instance, as additives in ion-conducting polyelectrolyte membranes.

\section{Conclusions}

Alumina nanoparticles were successfully functionalized using [2-(3,4-epoxycyclohexyl)ethyl]trimethoxysilane (a silane coupling agent). The acidic surface of alumina and particularly previous surface modification with arylsulfonates (AL-2 sample) caused degradation of the cyclohexene oxide (epoxide) moiety. The presence of arylsulfonate anions favored the cleavage of the epoxy ring, as evidenced by ${ }^{13} \mathrm{C}$ CPMAS NMR. This side-reaction facilitated the functionalization of the AL-2 sample, in comparison to the neat alumina sample (AL-1). The functionalization with the silane coupling agent imparted a hydrophobic character to the AL-S1 and AL-S2 alumina samples.

\section{Acknowledgements}

The authors thank the European Union and the Erasmus Munds Program for the financial support given to the present work. Prof. João Rocha and the NMR facility of University of Aveiro (Aveiro, Portugal) are acknowledged for the solid-state NMR spectra. The authors thank Prof. Gerald Schneider and the staff of the Institute of Advanced Ceramics Materials at TUHH (Hamburg, Germany) for the XRD measurements.

\section{References}

1. Joubert, J.; Delbecq, F.; Sautet, P.; J. Catal. 2007, 251, 507; Womes, M.; Le Peltier, R.; Morin, S.; Didillon, B.; OlivierFourcade, J.; Jumas, J. C.; J. Mol. Catal. A: Chem. 2007, 266, 55; Santos, R. K. S.; Batista, M. S.; Assaf, E. M.; Assaf, J. M.; Quim. Nova 2005, 28, 587; Buffon, R.; Jannini, M. J. D.; Abras, A.; Mol, J. C.; de Wit, A. M.; Kellendonk, F. J. A.; J. Mol. Catal. A: Chem. 1999, 149, 275; Sales, E. A.; Benhamida, B.; Caizergues, V.; Lagier, J. P.; Fievet, F.; BozonVerduraz, F.; Appl. Catal., A 1998, 172, 273.
2. Joubert, J.; Delbecq, F.; Coperet, C.; Basset, J. M.; Sautet, P.; Top. Catal. 2008, 48, 114; Wolke, S. I.; Buffon, R.; J. Mol. Catal. A: Chem. 2000, 160, 181; Basset, J. M.; Lefebvre, F.; Santini, C.; Coord. Chem. Rev. 1998, 178, 1703.

3. King, P. J.; Sappa, E.; Sciacca, C.; Inorg. Chim. Acta 2002, 334, 131; Allasia, C.; Castiglioni, M.; Giordano, R.; Sappa, E.; Verre, F.; J. Cluster Sci. 2000, 11, 493; Sica, A. M.; dos Santos, J. H. Z.; Baibich, I. M.; Gigola, C. E.; J. Mol. Catal. A: Chem. 1999, 137, 287; Baibich, I. M.; dos Santos, J. H. Z.; Stedile, F. C.; Santarosa, V. E.; Baumvol, I. J. R.; Polyhedron 1997, 16, 1937.

4. Ramos, A. R.; Arguello, J.; Magosso, H. A.; Gushikem, Y.; J. Braz. Chem. Soc. 2008, 19, 755.

5. Caiut, J. M. A.; Ribeiro, S. J. L.; Messaddeq, Y.; Dexpert-Ghys, J.; Verelst, M.; Dexpert H.; Nanotechnol. 2007, 18, 455605.

6. Amaral, R.; Ozcan, M.; Bottino, M. A.; Valandro, L. F.; Dent. Mater. 2006, 22, 283.

7. Hanemann T.; Compos. A: Appl. Sci. Manuf. 2006, 37, 735; Sim, L. C.; Ramanan, S. R.; Ismail, H.; Seetharamu, K. N.; Goh, J.; Thermochim. Acta 2005, 430, 155; Ji, Q. L.; Zhang, M. Q.; Rong, M. Z.; Wetzel, B.; Friedrich, K.; J. Mater. Sci. 2004, 39, 6487; Miyagawa, H.; Mohanty, A.; Drzal, L. T.; Misra, M. Ind. Eng. Chem. Res. 2004, 43, 7001; Bauer, F.; Glasel, H. J.; Decker, U.; Ernst, H.; Freyer, A.; Hartmann, E.; Sauerland, V.; Mehnert, R.; Prog. Org. Coat. 2003, 47, 147.

8. Atwater, J. E.; Akse, J. R.; J. Membr. Sci. 2007, 301, 76; Smuleac, V., Butterfield, D. A.; Sikdar, S.K.; Varma, R.S.; Bhattacharyya, D.; J. Membr. Sci. 2005, 251, 169; McCarley, K. C.; Way, J. D.; Sep. Purif. Technol. 2001, 25, 195.

9. Annais, R. S.; Ribeiro J. S.; Segatelli, M. G.; Yoshida, I. V. P.; Luccas, P. O.; Tarley, C. R. T.; Sep. Purif. Technol. 2007, 58, 122.

10. Pesek, J. J.; Thang, V. H.; Chromatografia 1994, 39, 649.

11. Schadler, L. S.; Brinson, L.C.; Sawyer, W.G.; J. Metals 2007, 59, 53; Wichmann, M. H. G.; Cascione, M; Fiedler, B.; Quaresimin, M.; Schulte, K.; Compos. Interface 2006, 13, 699; Fiedler, B.; Gojny, F. H.; Wichmann M. H. G.; Nolte, M. C. M.; Schulte, K.; Compos. Sci. Technol. 2006, 66, 3115.

12. Valandro, L. F.; Ozcan, M.; Bottino, M. C.; Bottino, M. A.; Scotti, R.; Della Bona, A.; J. Adhes. Dent. 2006, 8, 175; Yoshida, Y.; Shirai, K.; Nakayama, Y.; Itoh, M.; Okazaki, M.; Shintani, H.; Inoue, S.; Lambrechts, P.; Vanherle, G.; Van Meerbeek, B.; J. Dent. Res. 2002, 81, 270.

13. Hosseinpour, D.; Guthrie, J. T.; Berg, J. C.; Prog. Org. Coat. 2008, 62, 214; Hosseinpour, D.; Guthrie, J. T.; Berg, J. C.; Stolarski, V. L.; Prog. Org. Coat. 2005, 54, 182; Mingalyov, P. G.; Buchnev, M. V.; Lisichkin, G. V.; Russ. Chem. Bull. 2001, 50, 1693.

14. Rong, M. Z.; Ji, Q. L.; Zhang, M. Q.; Friedrich, K.; Eur. Polym. J. 2002, 38, 1573.

15. Canto, C. A.; Prado, L. A. S. A.; Radovanovic, E.; Yoshida, I. V. P.; Polym. Eng. Sci. 2008, 48, 141; Prado, L. A. S. A.; Karthikeyan, C. S.; Schulte, K.; Nunes, S. P.; de Torriani I. L.; 
J. Non-Cryst. Solids 2005, 351, 970; Jose, N. M.; Prado, L. A. S. A.; Yoshida, I. V. P.; J. Polym. Sci., Part B: Polym. Phys. 2004, 42, 4281; Prado, L. A. S. A.; Radovanovic, E.; Pastore, H. O.; Yoshida, I. V. P., Torriani, I. L.; J. Polym. Sci., Part A: Polym. Chem. 2000, 38, 1580.

16. Karthikeyan, C. S.; Nunes, S. P.; Prado, L. A. S. A.; Schulte, K.; ECS Trans. 2006, 3, 1297; Karthikeyan, C. S.; Nunes, S. P.; Prado, L. A. S. A.; Ponce, M. L.; Silva, H.; Ruffmann, B.; Schulte, K.; J. Membr. Sci. 2005, 254, 139.

17. Janosovits, U.; Ziegler, G.; Scharf, U.; Wokaum, A.; J. Non-Cryst. Solids 1997, $210,1$.

18. Li, Y.; Liu, J.; Jia, Z.; Mater. Lett. 2006, 60, 3586; GuzmánCastillo, M.L.; Hernández-Beltrán, F.; Fripiat, J. J.; RodriquezHernández, A.; García de León, R.; Navarrete-Bolaños, J.; Tobón-Cervantes, A.; Bokhimi, X.; Catal. Today 2006, 107, 874; Mishra, D.; Anand, S.; Panda, R. K.; Das, R. P.; Hydrometallurgy 2000, 58, 169.

19. Cardianoa, P.; Ponterio, R.C.; Sergi, S.; Lo Schiavo, S.; Piratino, P.; Polymer 2005, 46, 1847; Udagawa, A.; Yamamoto, Y.; Chûjô, R.; Polymer 1990, 32, 2425.

20. Pissetti, F. L.; Magosso, H. A.; Yoshida, I. V. P.; Gushikem, Y.; Myernyi, S. O.; Kholin, Y. V.; J. Colloid Interface Sci. 2007, 314, 38; Lazzarin, A.; Gushikem, Y.; J. Braz. Chem. Soc. 2002, 13, 88; Lewis, L. N.; Eraly, T. A.; Larsen, M.; Williams, E.A.; Grande, J. C.; Chem. Mater. 1995, 7, 1369.

21. Kalinowski, H. O.; Berger, S.; Braum, S.; ${ }^{13} C-N M R$ Spektroskopie, Georg Thieme Verlag: Stuttgart, 1984, ch. 3.

22. Lambert, J. B.; Johnson, S. C.; Xue, L.; J. Am. Chem. Soc. 1994, 116, 6167; Yahaoui, A.; Belbachir, M.; Soutif, J. C.; Fontaine, L.; Mater. Lett. 2005, 59, 759.

23. Gao, B.; Wen, Y.; Yang, Z.; Huang, X.; Liu, X.; Feng, X.; Adv. Synth. Catal. 2008, 350, 385; Williams, D. B. G.; Lawton, M.; Tetrahedron Lett. 2006, 47, 6557.

24. Canadell, J.; Mantecón, A.; Cádiz, V.; J. Polym. Sci., Part A: Polym. Chem. 2007, 45, 1980.

25. Hayase, S.; Onishi, Y.; Suzuki, S.; Wada, M.; J. Polym. Sci., Part A: Polym. Chem. 1983, 21, 467.
26. Chaker, J. A.; Santilli, C. V.; Pulcinelli, S. H.; Dahmouche, K.; Briosi, V.; Judeinstein, P.; J. Mater. Chem. 2007, 17, 744; Nunes, S. C.; Bermudez, V. D.; Silva, M. M.; Smith, M. J.; Morales, E.; Carlos, L. D.; Ferriera, R. A. S.; Rocha, J; J. Solid State Electrochem. 2006, 10, 203; Gonçalves, M. C.; Silva, N. J. O.; Bermudez, V. Z.; Ferreira, R. A. S.; Carlos, L. D.; Dahmouche, K.; Santilli, C. V.; Ostrovskii, D.; Vilela, I. C. C.; Craievich, A. F.; J. Phys. Chem. B 2005, 109, 20093; Nunes, S. C.; Bermudez, V. D. Z.; Cybinska, J.; Ferriera, R. A. S.; Legendziewicz, J.; Carlos, L. D.; Silva, M. M.; Smith, M. J.; Ostrovskii, D.; Rocha, J.; J. Mater. Chem. 2005, 15, 3876; Silva, N. J. O.; Amaral, V. S.; Bermudez, V. D.; Nunes, S. C.; Ostrovskii, D.; Rocha, J.; Carlos, L. D.; J. Mater. Chem. 2005, 15, 484.

27. Valente, J. S.; Falcón, S.; Lima, E.; Vera, M. A.; Bosch, P.; López-Salinas, E.; Microp. Mesop. Mater. 2006, 94, 277; Karthik, M.; Vinu, A.; Tripathi, A. K.; Gupta, N. M.; Palanichamy, M.; Murugesan, V.; Microp. Mesop. Mater. 2004, 70, 15.

28. Superti, G. B.; Oliveira, E. C.; Pastore, H. O.; Bordo, A.; Bisio, C.; Marchese, L.; Chem. Mater. 2007, 19, 4300.

29. Schiavon, M. A.; Redondo, S. U. A.; Pina, S. R. O.; Yoshida, I. V. P.; J. Non-Cryst. Solids 2002, 304, 92; Redondo, S. U. A.; Radovanovic, E.; Torriani, I. L.; Yoshida, I. V. P.; Polymer 2001, $42,1319$.

30. Inoue, M.; Kimura, M.; Inui, T.; Chem. Mater. 2000, 12, 55.

31. Prado, L. A. S. A; Yoshida, I. V. P.; Torriani, I. L.; J. Polym. Sci., Part A: Polym. Chem. 2010, 48, 1220; Chavez, R.; L. A. S. A.; Schulte, K.; Macromol. Mater. Eng. 2010, 295, 397; Prado, L. A. S. A; De La Vega, A.; Sumfleth, J.; Schulte, K.; J. Polym. Sci., Part B: Polym. Phys. 2009, 47, 1860; Ghislandi, M.; Prado, L. A. S. A; Oyervides, A. V.; Wittich, H.; Schulte, K.; Barros-Timmons, A.; J. Polym. Sci., Part A: Polym. Chem. 2008, 46, 3326; Werlang, M. M.; Yoshida, I. V. P.; de Araújo, M.A.; J. Inorg. Organomet. Polym. Mater. 1995, 5, 75.

Submitted: November 23, 2009 Published online: September 2, 2010 